\title{
Diencephalic Juvenile Pilomyxoid Astrocytoma with Leptomeningeal Dissemination
}

\section{Leptomeningeal Yaynlmmln Diensefalik Juvenil Pilomiksoid Astrositom}

\author{
Amit MAHORE ${ }^{1}$, Avinash KAMMAR ${ }^{1}$, Nitin DANGE ${ }^{1}$, Sridhar EPARI ${ }^{2}$, Atul GOEL ${ }^{1}$ \\ ${ }^{1}$ Kem Hospital, Department of Neurosurgery, Mumbai, India \\ ${ }^{2}$ Tata Memorial Hospital, Department of Neuropathology, Mumbai, India
}

Correspondence address: Amit MAHORE / E-mail: amit2mahore@yahoo.co.in

\begin{abstract}
Pilomyxoid astrocytoma (PMA) is a recently described neoplasm. PMA shares few features with pilocytic astrocytoma (PA), the most common central nervous system (CNS) tumor in the pediatric population, yet displays histological differences. Previous studies have shown that PMAs have more aggressive biological behavior as compared to PA. These findings suggest that PMA may be a unique and distinct neoplasm. We report a pilomyxoid astrocytoma of the hypothalamic-chiasmatic region with leptomeningeal dissemination in a 3-month old infant. This case report discusses the histological, clinical, and radiographic characteristics of PMA. In addition, the current treatment options and research potential involving this disease are also briefly described.
\end{abstract}

KEYWORDS: Pilocytic astrocytoma, Pilomyxoid astrocytoma, Pediatric brain tumors, Leptomeningeal dissemination

öz

Pilomiksoid astrositom (PMA) son zamanlarda tanımlanmış bir neoplazidir. PMA pediatrik popülasyonda en sık görülen merkezi sinir sistemi tümörü olan pilositik astrositomlarla (PA) bazı özellikleri paylaşır ancak histolojik farklılık gösterir. Daha önceki çalışmalar PMA ların PA ya kıyasla daha agresif biyolojik davranışa sahip olduklarını göstermiştir. Bu bulgular PMA nın kendine has ve ayrı bir neoplazi olabilecegini öne sürmüştür. Biz 3 aylık bir bebekte leptomeningeal yayılımı olan hipotalamik-kiazmatik bölge pilomiksoid astrositomu bildiriyoruz. Bu vaka sunumu PMA nın histolojik, klinik ve radyolojik özelliklerini tartışmaktadır. Ayrıca bu hastalıkla ilgili mevcut tedavi seçenekleri ve potansiyel araştırma alanları da kısaca tanımlanmıştır.

ANAHTAR SÖZCÜKLER: Pilositik astrositom, Pilomiksoid astrositom, Pediatrik beyin tümörleri, Leptomeningeal yayılım

\section{INTRODUCTION}

Pilomyxoid astrocytoma (PMA) is a recently described tumor entity. It has been designated PMA on the basis of its typical histological appearance $(4,8,12)$. We report disseminated pilomyxoid astrocytoma of the hypothalamic-chiasmatic region in a 3-month old infant. Greater recognition of this newly discovered neoplasm has the potential to change the prognosis and treatment of pediatric low-grade astrocytomas.

\section{CASE REPORT}

A male infant, born by full term normal labour, was brought at the age of three months with history of failure to thrive since one month. The patient had vomiting and seizures since two days. Physical examination at that time revealed a cachectic baby with a body weight of 2400 grams. The anterior fontanelle was full with prominent scalp veins. On examination, the baby was drowsy and the right pupil was larger than the left. The patient was not fixing on objects using the right eye although moving all the limbs normally.
Magnetic Resonance Imaging (MRI) of the brain and spine showed a multilobulated solid mass measuring $6 \times 6.5 \times$ $7.0 \mathrm{~cm}$ with the epicentre in the suprasellar region. The mass displaced the 3rd ventricle superiorly and to the right causing hydrocephalus. In addition, there were multiple leptomeninges-based enhancing lesions in the posterior fossa and spinal cord. (Figures $1 \mathrm{~A}-\mathrm{C}, 2$ ). Our provisional diagnosis was suprasellar germ cell tumor with dissemination.

A ventriculoperitoneal shunt and biopsy of the lesion through a right fronto-temporal craniotomy were performed. Histology of the biopsy specimen revealed a glial neoplasm consisting of tumour cells with highly elongated bipolar cytoplasmic processes (neoplastic pilocytes) arranged in a monomorphous, loose, micro cystic pattern, set against a striking myxoid background (Figure 3A). Cytological pleomorphism was minimal and mitoses were rare. Rosenthal fibers and eosinophilic granular bodies were absent. The tumor cells showed radiation around vessels in a cartwheellike fashion. Immunohistochemical staining for glial fibrillary acid protein was positive (Figure 3B-C). Postoperatively, 

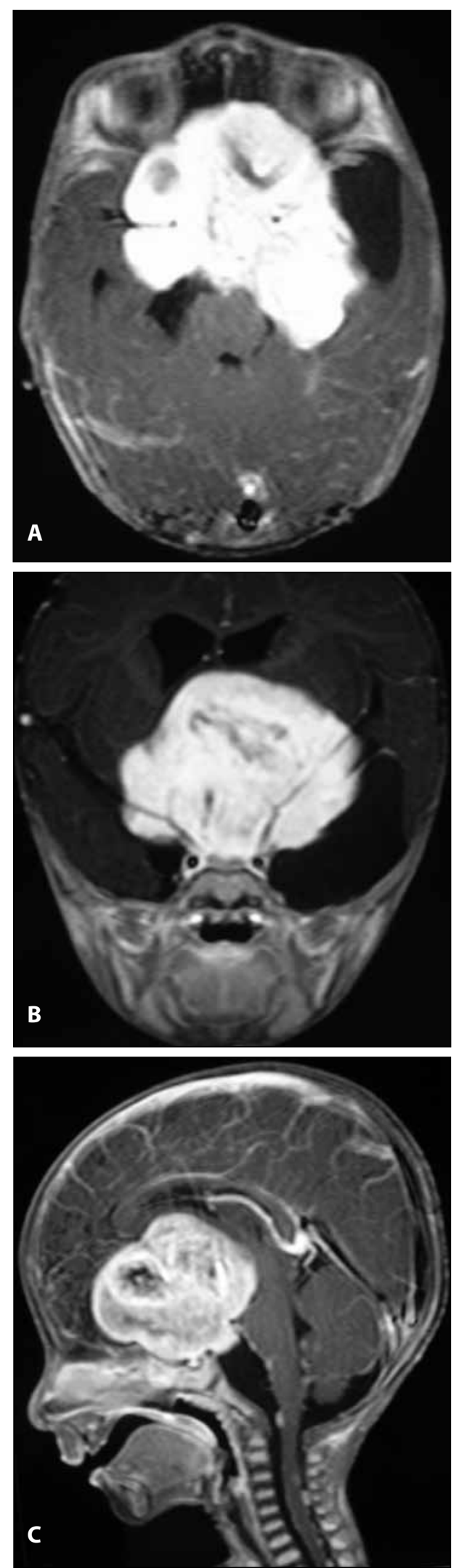

Figure 1A-C: Axial, coronal and sagittal views of brain MRI with gadolinium showing a solid enhancing tumour in the region of the suprasellar cistern. the patient's level of consciousness improved for two days but subsequently he developed generalized seizures and became drowsy following aspiration pneumonitis. He developed septicemia secondary to pneumonitis on the sixth postoperative day and expired in the intensive care unit after 13 days.

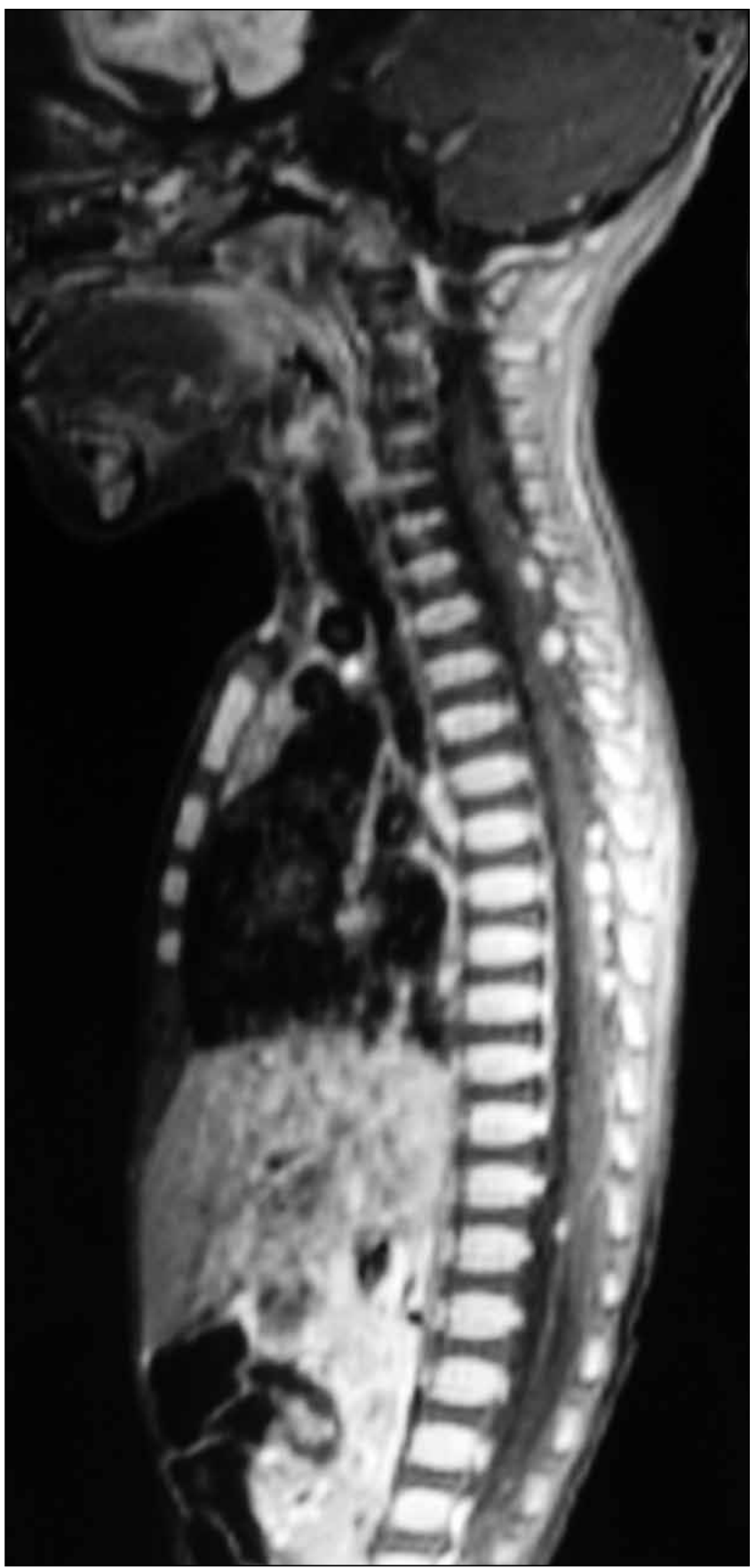

Figure 2: MRI of the spine showing multiple enhancing lesions in the subarachnoid space. 

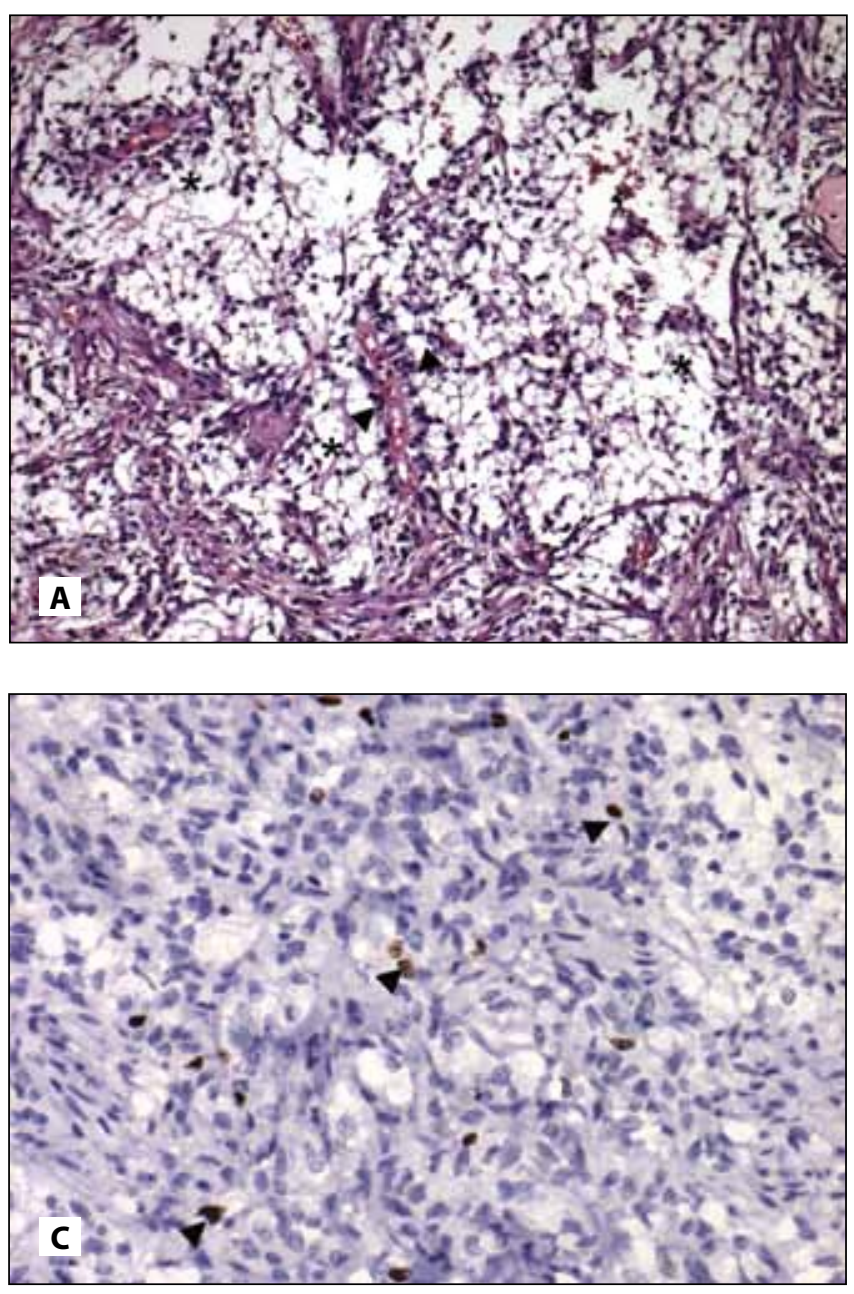

\section{DISCUSSION}

Originally described by Jänisch et al. (8) in 1985 as'diencephalic pilocytic astrocytoma with clinical onset in infancy', the term pilomyxoid astrocytoma was introduced in 1999 by Tihan et al. who also defined its characteristic histopathological features $(18,19)$. The PMA has been recommended by the WHO (World Health Organization) to be grade II, in contrast to juvenile pilocytic astrocytomas (JPA), which are considered to be WHO Grade I neoplasms $(11,12)$.

As in pilocytic astrocytomas, cerebrospinal metastases of pilomyxoid astrocytomas may be due to proximity of the tumor to the subarachnoid space, surgically induced dissemination of tumor cells or invasion of leptomeninges by the tumor $(5,6,13,14)$. PMAs may occur anywhere along the neuraxis but these tumors exhibit a predilection for the hypothalamic region and tend to affect younger age group as compared to JPA $(8,10,18,19)$. The mean age at diagnosis for patients with PMA has been documented to be 18 months $(10,11)$. Patients with PMA experience shorter progressionfree survival (PFS) and higher local recurrence than those with JPA $(10,11,12)$.

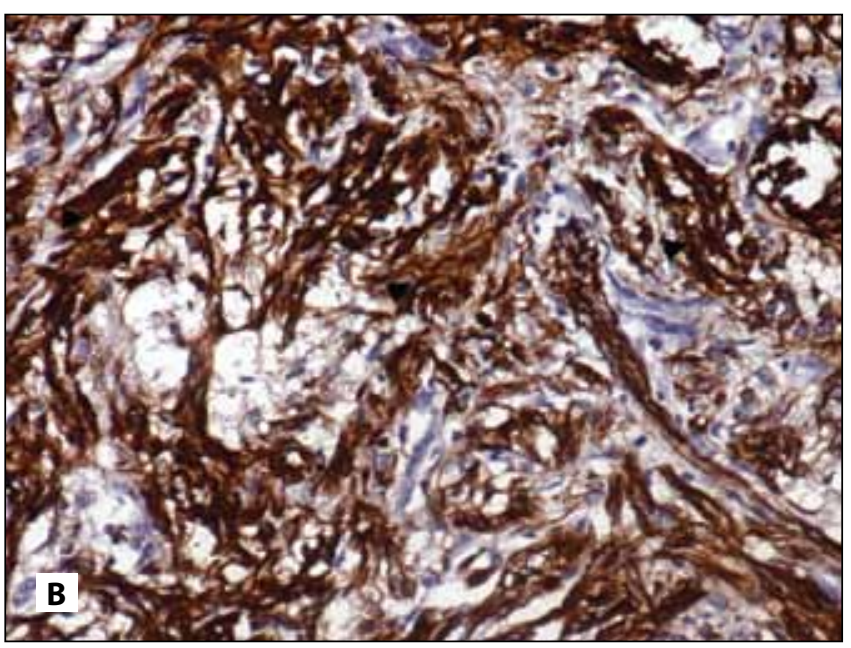

Figure 3: A) (H\&E; x100) Photomicrograph showing a tumor consisting of tumor cells arranged around the blood vessels (shown by a arrow heads) in a loose myxoid stroma (shown by an asterisk *). No Rosenthal fibers or eosinophilic granular bodies are seen. B) (IHC - GFAP; x200) Photomicrograph showing diffuse and strong immunoreactivity of tumor cells for glial fibrillary acidic protein as shown by the labeling of tumor cells by brown color. The areas of positivity are shown by arrow heads. C) (IHC - Mib-1, $x 200$ ). Photomicrograph for proliferation index of the tumor by immunohistochemistry for Mib-1 shows labeling index of 3-4\% of tumor cells (shown by arrow head) in the highest proliferating areas.

PMA most commonly presents with symptoms of raised intracranial pressure (ICP) or parenchymal compression $(10,11)$. Gait abnormalities, dysmetria, and nystagmus are common in children with a cerebellar tumor. An increase in head size may be the first symptom in babies. The presenting symptoms of hypothalamic juvenile PMA are vomiting, feeding difficulties, developmental delay and failure to thrive. $(8,10,14)$.

On MRI, these tumors are well circumscribed without evidence of peritumoral edema or parenchymal infiltration (2). The majority (84.6\%) are solid, with the remainder showing a minimal cystic component. Radiographic evidence of central necrosis is rare. With contrast administration, PMA tends to enhance homogeneously $(2,11)$.The fact that PMAs typically enhance homogeneously and demonstrate solid composition may enable early identification of PMA in the setting of an appropriate clinical history and patient age $(2,11)$.

Pilomyxoid histology consists of a markedly myxoid matrix, with small, compact, piloid, and highly monomorphous cells. Tumor cells are often arranged radially around vessels in a pattern that resembles the perivascular rosettes seen in ependymomas. Rosenthal fibers and eosinophilic granular 
bodies, both characteristic of pilocytic histology, are absent $(4,8,18)$. Infiltration of tumor cells into the surrounding neuropil may occur at the tumor periphery. Mitotic figures may be seen occasionally $(4,8,18,19)$.

As a recently discovered tumor entity, PMA is treated in a manner similar to PA (11). Gross total resection of tumor without unacceptable sequelae is the most powerful predictor of favorable outcome in pediatric gliomas $(15,21)$. The management of PMA is therefore greatly influenced by tumor location. Cerebellar tumors are often cured by surgery alone. This is in contrast to hypothalamic/chiasmatic tumors that are usually not amenable to gross total resection $(8,10$, 14).

Chemotherapy may be implemented for the treatment of inoperable or partially resected gliomas in infants and very young children $(3,20)$. Chemotherapy may serve to delay the need for radiation therapy in this patient population (7). Radiation therapy for low-grade astrocytomas is generally reserved for patients older than 5 years of age $(17,20)$.

Aggressive biological behavior and poor overall outcome of PMA may be attributed to some genomic differences with PA $(1,11,16)$. PMA tends to occur during infancy and early childhood, and report of occurrence in the setting of neurofibromatosis type 1 (NF-1) suggests that it may have a congenital or genetic origin with unique gene mutations. $(1,9,16)$ PMA genetics may allow the development of novel diagnostic and therapeutic strategies $(11,16)$.

Although PMA is considered an aggressive variant of juvenile pilocytic astrocytoma, PMA may be an entirely distinct clinicopathological entity. Further studies can address this question adequately. Clinical suspicion and early recognition of these tumors may change their prognosis and treatment.

\section{REFERENCES}

1. Allen JC: Initial management of children with hypothalamic and thalamic tumors and the modifying role of neurofibromatosis-1. Pediatr Neurosurg 32:154-162,2000

2. Arslanoglu A, Cirak B, Horska A, Okoh J, Tihan T, Aronson L, Avellino AM, Burger PC, Yousem DM: MR imaging characteristics of pilomyxoid astrocytomas. Am J Neuroradiol 24(9):1906-1908, 2003

3. Brown MT, Friedman HS, Oakes WJ, Boyko OB, Hockenberger B, Schold SC Jr: Chemotherapy for pilocytic astrocytomas. Cancer 71:3165-3172, 1993

4. Burger PC, Cohen KJ, Rosenblum MK, Tihan T: Pathology of diencephalic astrocytomas. Pediatr Neurosurg 32(4):214-219, 2000

5. Civitello LA, Packer RJ, Rorke LB, Siegel K, Sutton LN, Schut $\mathrm{L}$ : Leptomeningeal dissemination of low-grade gliomas in childhood. Neurology 38: 562-566, 1988

6. Darwish B, Koleda C, Lau H, Balakrishnan V, Wickremesekera A: Juvenile pilocytic astrocytoma 'pilomyxoid variant' with spinal metastases. J Clin Neurosci 11(6):640-642, 2004
7. Duffner PK, Horowitz ME, Krischer JP, Friedman HS, Burger PC, Cohen ME, Sanford RA, Mulhern RK, James HE, Freeman CR, Seidel FG, Kun LE: Postoperative chemotherapy and delayed radiation in children less than three years of age with malignant brain tumors. N Engl J Med 328:1725-1731, 1993

8. Janisch W, Schreiber D, Martin H, Gerlach H: Diencephalic pilocytic astrocytoma with clinical onset in infancy. Biological behavior and pathomorphological findings in 11 children. Zentralbl Allg Pathol 130:31-43, 1985

9. Khanani MF, Hawkins C, Shroff M, Dirks P, Capra M, Burger PC, Bouffet E: Pilomyxoid astrocytoma in a patient with neurofibromatosis. Pediatr Blood Cancer 46(3):377-380, 2006

10. Komotar RJ, Burger PC, Carson BS, Brem H, Olivi A, Goldthwaite PT, Tihan T: Pilocytic and pilomyxoid hypothalamic/chiasmatic astrocytomas. Neurosurgery 54:72-79, 2004

11. Komotar RJ, Mocco J, Carson BS, Sughrue ME, Zacharia BE, Sisti AC, Canoll PD, Khandji AG, Tihan T, Burger PC, Bruce JN: Pilomyxoid astrocytoma: A review. Med Gen Med 6 (4):42, 2004

12. Louis DN, Ohgaki $H$, Wiestler OD, Cavenee WK, Burger PC, Jouvet A, Scheithauer BW, Kleihues P: The 2007 WHO classification of tumours of the central nervous system. Acta Neuropathol 114(2):97-109, 2007

13. Mamelak AN, Prados MD, Obana WG, Cogen PH, Edwards MS: Treatment options and prognosis for multicentric juvenile pilocytic astrocytoma. J Neurosurg 81:24-30, 1994

14. Perilongo G, Carollo C, Salviati L, Murgia A, Pillon M, Basso G, Gardiman M, Laverda A: Diencephalic syndrome and disseminated juvenile pilocytic astrocytomas of the hypothalamic-optic chiasm region. Cancer 80:142-146, 1997

15. Pollack IF: The role of surgery in pediatric gliomas. J Neurooncol 42:271-288, 1999

16. Shai R, Shi T, Kremen TJ, Horvath S, Liau LM, Cloughesy TF, Mischel PS, Nelson SF: Gene expression profiling identifies molecular subtypes of gliomas. Oncogene 22:4918-4923, 2003

17. Tarbell NJ, Loeffler JS: Recent trends in the radiotherapy of pediatric gliomas. J Neurooncol 28:233-244, 1996

18. Tihan T, Burger PC: A variant of pilocytic astrocytoma: A possible distinct clinicopathological entity with a less favourable outcome. J Neuropathol Exp Neurol 57: 500, 1998

19. Tihan T, Fisher PG, Kepner JL, Godfraind C, McComb RD, Goldthwaite PT, Burger PC: Paediatric astrocytomas with monomorphous pilomyxoid features and a less favorable outcome. J Neuropathol Exp Neurol 58: 1061-1068, 1999

20. Urban C, Benesch M, Pakisch B, Lackner H, Kerbl R, Schwinger W, Oberbauer R: Synchronous radiochemotherapy in unfavorable brain tumors of children and young adults. J Neurooncol 39: 71-80, 1998

21. Wisoff JH, Boyett JM, Berger MS, Brant C, Li H, Yates AJ, McGuireCullen P, Turski PA, Sutton LN, Allen JC, Packer RJ, Finlay JL: Current neurosurgical management and the impact of the extent of resection in the treatment of malignant gliomas of childhood: A report of the Children's Cancer Group trial no. CCG-945. J Neurosurg 89:52-59, 1998 